system of levers so arranged as to cause an equal pressure on 9 out of 12 portions of equal area of the lower face of the mirror, the remaining 3 portions being supported on adjusting screws for squaring the mirror. Nine weighted levers mounted on universal joints compensate for the side pressure of the mirror, these levers being out of action when the tube is vertical, and gradually coming into action as the tube is moved towards the horizontal. These systems of levers are similar to those used in the sixty-inch Mount Wilson telescope.

The main part of the tube is built of flat tapered strips of duralumin laid in right- and left-hand spirals and stiffened inside at intervals with steel angle rings, the upper end of the tube having a flanged ring to which either of the two hoods provided can be attached. The first, or Newtonian hood, is provided with a handwheel, so that it can be rotated to bring the eyepiece into a position convenient for the observer, the diagonal mirror being supported by four thin steel bands five inches wide, placed edgewise. On the side of this hood is mounted a flange to which either a visual or photo breechpiece can be attached by a bayonet joint-while a little to one side is placed a finder having an aperture of two inches. The photo breechpiece is arranged to take plates $80 \mathrm{~mm} . \times 80 \mathrm{~mm}$., and is fitted with cross slides and guiding microscopes.

The second or Cassegrain hood has a box-shaped aluminium casting mounted in the centre and supported on four thin steel bands. The Cassegrain mirror of I2 inches diameter, with its focussing arrangements, is attached by a bayonet joint to the lower face of this casting, and the Newtonian photo breechpiece can be attached to the upper face, so that when the Cassegrain mirror mounting is removed, photographs can be taken in the prime focus. The mirror focussing gear is actuated by a handwheel mounted at the lower end of the tube. The rays reflected from the Cassegrain mirror are received on a small diagonal mirror mounted on four springs about twelve inches in front of the great mirror and reflected at right angles to the axis of the tube through the flange formed on the side of the centre casting, arranged to take the breechpieces or spectrograph.

The telescope is also arranged so that a fixed spectrograph can be used. For this purpose a plane mirror is provided which can be mounted on a hollow shaft passing through one of the trunnions forming the declination axis, this mirror being arranged to move at half the speed of the tube when the latter is moved in declination. This mirror directs the rays from the Cassegrain mirror down through the hollow polar axis. Fixed on one side of the tube is a guiding telescope of 7 inches aperture and about I 3 feet focal length, fitted with eyepiece on cross slides.

The quick, quick-slow, and slow-slow motions in Right Ascension, as well as the quick motion in Declination, are all electrically operated and controlled by push buttons from any convenient position.

The telescope is mounted in a revolving dome of 32 feet internal diameter, carried on steel pillars I6 feet high, a floor being attached to the pillars I 2 feet above the level of the ground. The dome has a double shutter giving an opening II feet wide at the bottom, $5 \mathrm{ft} .6$ in. wide at the top, and extending 4 feet beyond the zenith. The observing platform is carried on rails mounted in the revolving portion of the dome, and has a transverse motion of about 4 feet parallel to the opening. This platform has a stairway attached to it, with rails on each side of the steps, at an angle of $45^{\circ}$, up and down which runs the observing carriage, controlled electrically, and fitted with cut-outs to limit the travel. The revolution of the dome can be controlled from this carriage, or any other convenient position.

A truck fitted with three screw-jacks is provided for removing the mirror cell and mirror from the tube, and for raising the mirror out of the cell, for the purpose of resilvering.

\title{
New Agriculture Building at the University of Leeds.
}

$\mathrm{O}^{\mathrm{N}}$ Friday, April 4, the Rt. Hon. Noel Buxton, Minister of Agriculture and Fisheries, laid the foundation stone of the new building for the Department of Agriculture at the University of Leeds. The proceedings were presided over by the Chancellor of the University (His Grace the Duke of Devonshire), and after the laying of the stone the Minister gave an address at a public meeting in the Great Hall of the University. There was a large company of landowners, farmers, and other friends of the University present, and much interest was manifested in the proceedings.

The building, which has been designed by $\mathrm{Mr}$. Paul Waterhouse, will occupy a plot I9o feet long by I 25 feet deep. The basement will be used for stores, and will also contain a students' common room, and a large machinery room and workshop, etc. On the ground floor there are two lecture rooms, a museum, library, and administrative offices. The Biological Department on the first floor will include a general laboratory, lecture room, research rooms, an advanced laboratory, one or two private rooms, preparation, sterilising, and store rooms, etc. The Chemical Section is provided for on the second floor, and includes a large students' laboratory, laboratories for chemical nutrition research, balance rooms, large and small lecture rooms, and rooms for microscopy and other special purposes. The roof surface will be adapted for out-of-door and greenhouse work. The new building will cost $60,000 l$, towards which the

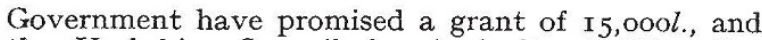
the Yorkshire Council for Agricultural Education Io,oool., while there have been also some handsome donations.

At the meeting in the Great Hall of the University after the ceremony, the Duke of Devonshire, in extending a cordial welcome to $\mathrm{Mr}$. Buxton, indicated the opportunity which the new building would afford to enable research work to be carried on under more comfortable, happier, and favourable conditions. He hoped this would only be an augury of further development.

Major Dent, chairman of the Yorkshire Council for Agricultural Education, spoke of the progress of the work of the Department of Agriculture of the University since its establishment in I89r, and of the principles which had guided the Council. There was one body responsible for agricultural education for the whole geographical County of Yorkshire, consisting of representatives of the three County Councils, the University, the Ministry of Agriculture, and a few additional members. He referred to the amicable relations that had existed amongst the various authorities, and how co-operation and interest had been secured with the Farmers' Union. Much had been accomplished from a small beginning in the domain of agricultural economics, and great extension had taken place in the advisory work of the Department.

Mr. Noel Buxton, in referring to the honour it gave

NO. 284 I, VOL. I I 3$]$ 
him to represent the Government, stated he was voicing the general feeling of the Cabinet when he said how deeply they appreciated the work that was being done by Yorkshire and by the University of Leeds in promoting the cause of agricultural education. What the Agricultural Department had hitherto lacked in the way of suitable accommodation had been made up by the zeal and energy of those connected with it. There was no more useful way in which the Ministry could spend money than on agricultural education, and a return from such expenditure was yielded which could not be expressed merely in cash. Schemes of agricultural education were also outside party controversy, and were therefore, he hoped, not likely to be diminished with any change of Government. Governments had realised the vital importance of ensuring that agriculture derived the maximum assistance which it was in the power of science to render.

Mr. Buxton said that in the agricultural education of a generation ago it was not sufficiently realised that the science of accountancy was one of the foundation stones of farming, which was essentially a business that must be judged by results. Consideration of costs, whether of materials or labour, must everywhere dominate the treatment of the subject. What had been done by the University in that respect was recognised throughout the whole country.

There remained the question of the technical education of the young labourers, a field of work which, Mr. Buxton felt, had not received sufficient attention. The Ministry of Agriculture Scholarships Scheme for sons and daughters of agricultural workmen and other rural workers established two years ago provided a great opportunity for the gifted ones, but the Scheme had not been taken up to such an extent as was desirable. It was obvious, however, that a scheme for taking farm labourers from their occupations and maintaining them at considerable expense to the State at residential colleges could not touch the root problem of how to raise the standard of knowledge generally among the three-quarters of a million workers engaged in agriculture. As the labourer could not go to the Institution, the teacher must go to the farm. Instruction must be given under the guidance of the best craftsmen the district can produce. This was a matter which the Yorkshire Council for Agricultural Education and the University might most usefully explore in co-operation with the National Farmers' Union on the one hand and the organisations of agricultural labourers on the other.

The Pro-Chancellor (Mr. E. George Arnold) proposed, and the Pro-Vice-Chancellor (Prof. Jamieson) seconded, a most cordial vote of thanks to the Minister for his speech.

\section{University and Educational Intelligence.}

BirmingHAM.-The following appointments have been made: Mr. W. Billington, to be joint-professor of surgery; Dr. H. Black, to be lecturer in radiology; Mr. J. Humphreys, to be honorary reader in medieval archæology, for a period of three years; Mr. C. G. Burton, to be secretary of the University on the retirement of Mr. G. H. Morley at the end of this year. Mr. Burton will begin his duties as deputy secretary on June $x$, and will act in that capacity until Mr. Morley relinquishes office.

Negotiations with the War Office as to reparations to the Edgbaston buildings necessitated by their use as the rst Southern General Hospital during the War have now been satisfactorily completed.

The late Miss Caroline Harrold, of Church Road, Edgbaston, has left the residue of her estate to the University of Birmingham for affording facilities for research in the faculties of science and medicine.
CAmbridge.-Mr. Sidney Wynn Graystone, of Knightsbridge, formerly of White Lodge, Cheveley, Newmarket, who died on February 8 last, bequeathed to Downing College, of which he was a member, his collection of books, pictures, engravings, and etchings ; also, on the death of his wife and brother, the ultimate residue of his estate, which will probably exceed $75,000 l$. The testator directs that the sum of $5000 l$. shall be devoted to scholarships, $5000 l$. to the erection of a chapel, 500ol. to the erection of a Graystone Library, and the remainder to the erection of additional college buildings to be called the Graystone Block. This munificent bequest, when it becomes available, will enable the governing body to provide the urgently needed additional accommodation for students within the college. The Graystone bequest is by far the most valuable benefaction which Downing College has received since its foundation at the beginning of the last century.

Mr. J. Barker, Trinity College, has been elected to the Frank Smart University Studentship in Botany.

LoNDON.-The Presentation for Degrees will take place in the Royal Albert Hall, Kensington Gore, on Wednesday, May I4, at 2.30 P.M.

Applications are invited for the chair of mathematics tenable at Royal Holloway College. The latest date for the receipt of applications (to be sent to the Academic Registrar, University of London, South Kensington, S.W.7) is May I3.

OXFORD.-Lecturers or demonstrators are required at the Forestry Institute in the subjects of silviculture, mycology and pathology of trees, structure and properties of wood, economics of forestry (including statistical methods), and soil science. Further information can be obtained from the Secretary of the Institute, to whom the applications with testimonials and, if possible, copies of published writings should be sent by, at latest, July ${ }_{5}$.

THE trustees of the South African Museum, Cape Town, invite applications for the directorship of that institution in succession to the late Dr. L. Péringuey.

THE National Union of Students of the Universities and University Colleges of England and Wales, established two years ago, has hitherto directed its efforts mainly to bringing together students of different countries and working towards broadening the basis and outlook of the Confédération Internationale des Etudiants, to which it is affiliated. The fifth number of its National Union News, a very creditable production, is almost wholly devoted to its international interests and activities, chiefly to accounts of international gatherings held last September in London and Oxford. These bear evidence of strenuous and apparently successful efforts to bring about an appeasement of international animosities and a substantial measure of practical co-operation between student bodies of the various countries represented. The leaders of the delegations unanimously agreed at Oxford to issue to all countries a manifesto declaring that it was the wish of the Confederation to become really international and to include the students of all countries. It was agreed that students of the late neutral countries should prepare the way for the admission of German students. Interesting descriptions are given of several " faculty" tours organised by the N.U.S. : of chemistry students in Czecho-Slovakia, of students of agriculture in Denmark, and of medical students in Holland, Germany, Czecho-Slovakia, Austria, Switzerland, and France. Mr. W. Randerson, the Albert Kahn fellow for I923-24, has undertaken to contribute a series of articles on student life and activities in the countries visited by him in the course of his fellowship tour.

$$
\text { NO. } 284 \text { I, VOL. I I } 3]
$$

